\title{
PRODUCTION OF PLASTER OF PARIS USING SOLAR ENERGY
}

\author{
H.N. Acharya ${ }^{1}$, Ajay Chandak ${ }^{2}$ \\ ${ }^{1}$ Former Professor and head department of physics, Indian Institute of Technology Khararpur, \\ ${ }^{2}$ PRINCE, Suman Foundation, Shamgiri, Agra Road, Deopur, DHULE \\ harnarayan@gmail.com, renewable.india@gmail.com
}

\begin{abstract}
Plaster of Paris (POP) is an important building material. Most of the units producing POP are in small scale sector. These units use wood, coal to calcine gypsum. The average consumption of wood to produce one ton of POP is $300 \mathrm{~kg}$. The electrical energy constitutes only 5\% while rest is thermal energy. Most of POP units are situated in western Rajasthan. This region has about $300-320$ days of clear sun shine. Since thermal energy has major contribution in energy mix, it makes sense to supplement the same with concentrated solar technology. Experiments were conducted to establish feasibility. A commercial parabolic concentrator of 4 sqm was used to calcine small samples (5kg) and the result show great promise. An industrial method of producing POP using commercially available solar concentrator technologies (CST) has been proposed. The payback period is observed to be of the order of 4 years.
\end{abstract}

Keywords: Gypsum, Plaster of Paris, Solar energy, Scheffler reflector, parabolic concentrator $* * *$

\section{INTRODUCTION}

Plaster of Paris (POP) is chemically hemihydrates of calcium sulfate $\left(\mathrm{Ca} \mathrm{SO}_{4} 1 / 2 \mathrm{H}_{2} \mathrm{O}\right)$. It is produced by calcination / heating of gypsum, a di-hydrate of caocium sulfate $\left(\mathrm{Ca} \mathrm{SO}_{4} 2 \mathrm{H}_{2} \mathrm{O}\right)$. It has applications in construction industry, ceramic industry, sculptures, chalk pieces, medical (dental and surgical) etc. Most of the units producing POPs are in small scale sector with capacity ranging 10-20 T/D, only a small number of units are in large scale sector 100-200T/D.

The POP units use both thermal (wood, coal and diesel) and electrical energy for the production of POP(Plaster Of Paris).The electricity consumption is only $5 \%$ of total energy used thus the cost of producing POP depends on the cost of thermal energy, which is increasing every month. On an average a rotary kiln calciner uses about $300 \mathrm{~kg}$ of wood per ton [1].The monthly average energy consumption is of the order of 15000 $\mathrm{kWh}$ per ton. Since energy used is in thermal form, it makes sense to use concentrating solar power technology to generate required process heat. Maximum numbers of POP manufacturing units are based in western Rajasthan. This region has clear sun shine for about 300-320 days in a year. Solar resource map show that this region receives more than $6 \mathrm{kWh}$ per day, which shows suitability of the site. The Indian CST industry has developed good expertise to tap the solar thermal energy with 40 to $70 \%$ efficiency, using tracking type concentrators.

If we assume efficiency of collection as $60 \%$ then each meter square of concentrator will generate around $4 \mathrm{kWh}$ in a day with dual axis true parabolic concentrators. Even a fixed focus Scheffler dish can generate about $40 \mathrm{kwh}$ in a day. Salman and Khraishi [2] studied the decomposition of lime and gypsum using solar energy. Narendra et al [3] proposed use of solar energy in calcining gypsum, however, actual experiments were simulated with electrical energy. Present paper reports results of experiments done to calcine gypsum for production of POP using a commercial parabolic solar concentrator of 4 sqm and a proposed commercial method for production of POP using solar thermal energy.

\section{PLASTER OF PARIS; REVIEW OF MANUFACTURING PROCESSES}

The gypsum is a mineral available all over the world, it is also produced as a byproduct of fertilizer industry. In India the largest deposits are in Rajasthan followed by Tamilnadu, Jammu, Gujrat ,UP, MP and West Bengal. The gypsum is used in the manufacture of hydraulic cements, ammonium sulfate fertilizer, sulphuric acid, and reclamation of acidic soil for agricultural purpose. Chemically gypsum is $\mathrm{CaSO}_{4} \cdot 2 \mathrm{H}_{2} \mathrm{O}$, and has a molecular weight of 177.17

\subsection{Plaster of Paris}

The plaster of Paris, is a white binder produced from gypsum by removing water of crystallization .This is done by heating the raw gypsum at temperatures of the order of $120-180^{\circ} \mathrm{C}$. This removal of water is described by equation[1]

$$
\begin{aligned}
& \mathrm{CaSO}_{4} \cdot 2 \mathrm{H}_{2} \mathrm{O}+\Delta \mathrm{H} \rightarrow \mathrm{CaSO}_{4} \cdot \frac{1}{2} \mathrm{H}_{2} \mathrm{O}+\frac{3}{2} \mathrm{H}_{2} \mathrm{O}(1) \\
& \Delta \mathrm{H}=597,200 \mathrm{~kJ} / \mathrm{ton}=142,600 \mathrm{kcal} / \mathrm{T}=165.9 \mathrm{kWh} / \mathrm{T}
\end{aligned}
$$




\subsubsection{Manufacturing Processes for Plaster of Paris}

Gypsum as such does not possess binding properties. Industrial importance of gypsum is attributed to production of hemi-hydrate, obtained by heating gypsum to temperature in the range $120-180^{\circ} \mathrm{C}$. Gypsum plaster is manufactured in different grades like medical, building and pottery grades. The production of different grades needs controlling calcining parameters. There are many methods of manufacturing POP. Some commonly used techniques are discussed.

\subsection{Gypsum Calciners}

\subsubsection{Rotary Drum Calciner}

The rotary drum calciners are horizantal drums, made up of mild steel.These rotates along a horizontal shaft at slow speed of 10-12 rpm. The capacity of drum is about one ton. The batch time varies from 1 hour to 4 hours. The time depends on quality of desired product and end use of product .The drum is heated from bottom by fire wood. On the average $300 \mathrm{~kg}$ of wood is used to calcine one ton of gypsum[1].The dried gypsum powder is loaded manually.Dust emission occurs during loading un loading and during rotation of drum, steam is ejected,and along with steam dust is also emitted This emission of dust causes loss of heat.In this system heat from flue gases is not recovered, and the process emits $\mathrm{CO}$ and particulate matter, mostly carbon.

\subsubsection{Pan Type Calciners}

The Pan type calciners are stationary vertical cylindrical drums. Powdered gypsum is loaded manually. In earlier models they were heated by fire wood. In this process material is heated in two stages: pre-heat chamber (where it is heated up to $80-100^{\circ} \mathrm{C}$ through flue gases of main chamber) and in the main chamber the charge is heated up to desired temperature of $180^{\circ} \mathrm{C}$ for 3-4 hours .Batch capacity of these calciners is $600-800 \mathrm{~kg}$.

The CBRI has suggested [3] a double walled cylindrical calciner. The gypsum is heated by circulating hot thermic fluid in outer shell. The powdered material is gently agitated by a pedal agitator.

\subsubsection{Kettle Calciner}

These are the continuous type of calciners used in large scale unit producing POP at the rates 10-12 T/hour. The temperature of calciner is about $160^{\circ} \mathrm{C}-180^{\circ} \mathrm{C}$. The amount of heating oil used is about 28-32 liters/ton. Loading and un- loading is done automatically. Heat from flue gases is recovered.

\subsubsection{Fluidized Bed Technique of Producing POP}

\subsubsection{Principle of working}

The main principle of drying system using fluidized technique is to fluidize the powdered gypsum by a root blower blowing hot air from bottom of the boiling furnace body. The chamber is heated by delicate and intensive net work of steel pipes. A heat conductive oil/steam is circulated in these coils; this circulating fluid releases the heat into the inside of furnace. There is a roots blower under the bottom of boiling furnace, and it blows hot air into the furnace, until powder is in boiling status. Under a certain temperature, the dried and dehydrated powder becomes lighter, and gets carried away with hot air automatically. The quality of this kind of gypsum powder is stable, because the equipment adopts dried electrostatic dust remover, so the dust-removing efficiency is above $95 \%$. The fluidized bed technique there are no moving parts.

\subsection{Energy Used In Calcining Gypsum.}

Thermodynmic calculation predict [1] that $166 \mathrm{kWh}$ is needed to calcine one ton gypsum. Different calciners have different energy efficiency. The rotary calciner is most in efficient in terms of heat utilization, besides it emits large amount of dust and smoke. The Pan type calciner suggested by CBRI uses thermic fluid for heating, It appears that the most efficient technique is fluidized technique. In this both thermic fluid and steam can be used to heat the charge to required temperature. The systems using steam are comparatively less efficient in comparison to the thermic fluid. To minimize the capital cost of solar concentrating system the most efficient method of calcination must be tied up with such systems.

\section{EXPERIMENTAL FEASIBILITY OF USING SOLAR ENERGY TO PRODUCE POP}

To test the feasibility of using solar heat for calcination of gypsum was carried out in December 2012. Experiments were conducted at hotel Gaj Kesri Bikaner using their parabolic solar cooker, PRINCE-40, a model developed by PRINCE group. This cooker can cook $5 \mathrm{~kg}$ rice in an hour. Gypsum was powdered and placed in a household pressure cooker with blackened bottom. After about 5 minutes steam started coming out from top of cooker, indicating starting of dehydration process. The cooker was frequently shaken to homogenize the product. In around 30 minutes steam stopped coming out signaling end of dehydration. The pressure cooker was removed, and allowed to cool. The product was tested for setting time and whiteness. It took around 13 minutes for setting the plaster. The whiteness was the best for product obtained from selinite crystals. The experiment was repeated many times using gypsum from open cast mines and crystalline form, giving almost similar results. The experiments conclusively proved that solar concentrators can be a feasible technology for dehydrating gypsum.

\subsection{Solar Concentrator Technologies for Producing POP}

Having proved the experimental feasibility of calcining gypsum, the next task is to determine what kind of CST can be used? Since the initial cost of CST is high it is necessary to use most efficient calcining process. This rules out direct heating system 
employed in rotary kiln. Using thermodynamic calculation as a guide we attempt to select a CPT and determine its economic viability.

As mentioned in section 2.1 around $170 \mathrm{kWh}$ are required [1] to calcine one ton gypsum. This energy has to be supplied either by steam generated or by thermic heated by a CST. The heating by steam is less efficient compared to system based on thermic fluid.

There are a number of CSTs available commercially. Some of these show excellent potential for adoption for this application. Some of these are discussed herewith.

\subsubsection{Scheffler reflector}

These are flexible surface paraboloidal dishes and have fixed focus. It has a polar axis tracking for day movement while seasonal movement is required once in 3-4 days. The geometry of the parabola changes as per seasonal adjustment. Most common size of Scheffler concentrator at present is of 16 square meters. Many steam systems have been installed by Gadhia solar[5] for cooking at Bhram kumara Ashram, Abu, Rajasthan, Tirumala temple Andhra Pradesh, Shirdi Sai temple Maharashtra etc. There are known 95 sites till 2011 and many more are added every year. . The total energy produced by these dishes for eight hour in a day is about $37840 \mathrm{kcal}$ i.e. @ $41.63 \mathrm{kWh}$ [2]. In western Rajasthan one can anticipate the output in the range of 45-50 kWh because of higher insolation.

\subsection{System Design Calculations}

For production of one ton of POP the energy required as per equation 1 is $170 \mathrm{kWh}$. Assuming each dish produces $48 \mathrm{kWh}$ per day in Bikaner, the number of Scheffler dishes needed would be 29 say 30 dishes. Govt. of India provides subsidies for adoption of these technologies in the range of 30 to $40 \%$. In addition $80 \%$ accelerated depreciation is allowed which turns out to be $24 \%$ cash inflow in first year. The cost per dish is Rs. 3.00 lakh and with subsidy the cost will be in the range of Rs. 1.5 to 2 lakhs. Hence the project cost will be Rs. 45 to 60 lakhs depending on the financial incentives availed. Cost of firewood is at Rs. 4000/- per ton and at firewood consumption of $300 \mathrm{~kg}$ per ton of POP, the industry spends around Rs 1200/ton on firewood. In a 8 ton/day factory fuel cost would be Rs 9600/-, which amounts to Rs. 30 lakhs per year for 320 days operation. Thus the cost of project can be recovered in less than two years. If we assume cost of installing energy efficient system to be 50 lakhs, another 2 years would be needed to recover this cost. These dishes can also be used to generate hot air for use in heating fluidized furnaces.

\subsection{Dual Axis Tracked Parabolic Dish Concentrators.}

These parabolic systems employ duel axis sum tracking. They are the choice for heating thermic fluid to the temperatures needed in fluidized bed calciners. Mr. Prashant CEO of Vinayak
Gypsum, Mumbai, a firm specializing in manufacturing fluidized bed drier quotes the requirement of thermic oil heated to a temperature of $250^{\circ} \mathrm{C}$. Such high temperature cannot be achieved by Scheffler dishes and it is necessary to use dual axis tracked parabolic dishes. In India at present two options are available as ARUN dishes in 100 and 169 sqm while Megawatt dishes in $90 \mathrm{sqm}$ [7]. In both the cases a system delivering 40000 $\mathrm{kcal} /$ hour systems would cost around 22 lakh. Considering the subsidies of MNRE and accelerated benefits as in case of Scheffler dishes, the economics work out is similar with payback period of around 2 years with financial incentives and up to 4 years if financial incentives are not used.

\section{CONCLUSIONS}

Gypsum has been calcined using commercial parabolic cooker having diameter of $4 \mathrm{sqm}$. An industrial plant for producing plaster of Paris has been proposed using commercially available solar concentrators. The payback time has been estimated to be of the order of 2 to 4 years.

Acknowledgements

The authors would like to thank Mr. N.D.Vyas and Mr. Damodar Sharma, for help in conducting experiments. He would like to thank Mr. Deepak Gadhia, Dr. Anurag Acharya, Mr. Siddharth Maklik ,and Mr. Prashant, for helpful suggestions.

\section{REFERENCES}

[1] Development of environmental standards and preparing comprehensive industry document for plaster of paris industries. Central pollution control board,ministry of environment and forests, available at www.cpcb.nic.inCOINDS/74/2007 accessed on 23-3-2013.

[2] S.S. Davange and Archana Thosar (2012): 'Performance analysis of solar heating steam cooking system', Proceedings of third biennial national conference NCNTE, Feb 24-25 2012.

[3] O.A Salman and N Khraishi (1988), Thermal decomposition of Lime stone and gypsum using solar energy, Solar Energy, Volume 41 pg. 304-308

[4] Narendra Kumar, S.N. Saini, Sameer: Partial replacement of conventional heat energy by solar energy in the production of Gypsum plaster, available at http://www.cbri.res.in/index.php?option=com_content\&vie $\mathrm{w}=$ article $\& \mathrm{id}=83$ : gypsum-products\&catid=37: $\mathrm{s}-\mathrm{a}-\mathrm{t}-\mathrm{know}-$ how\&Itemid=86 accessed on 23-3-2013.

[5] Gadhia Deepak (2009), "Parabolic Solar Concentrators for Cooking and Food Processing", International Solar Food Processing Conference 14-16 January 2009, Indore, India. Pg. 1-5.

[6] Chandak Ajay, Somani Sunil and Chandak Anurag (2011), 'Development of PRINCE-40 Solar Concentrator as Do It Yourself (DIY) Kit, Proceedings of 'ISES Solar World Congress, Kassel, Germany 28 Aug. 2011 to 2nd Sept. 2011 PP 1-8. 
[7] Siddharth Mallik (2013): Presentation at 'Workshop on Solar Concentrator Technologies' at Dehradun organised by MNRE under UNDP-GEF program, 23rd March 2013.

\section{BIOGRAPHIES}

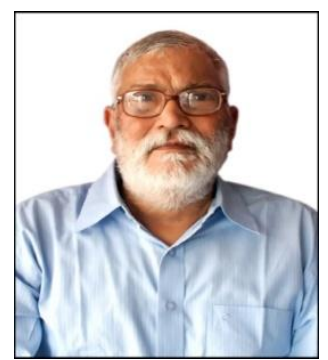

H.N.Acharya,was born on 20th January 1943 in Bikaner ,Rajasthan .India.He obtained Ph.D degree from IIT Kharagpur in 1972. He has: published more than 150 papers published in reputed journals, supervised $21 \mathrm{PhDs}$. 13 Indian patents are granted to him.. He retired from IIT Kharagpur, as a professor of physics in 2005, now settled in Bikaner Rajasthan, India.

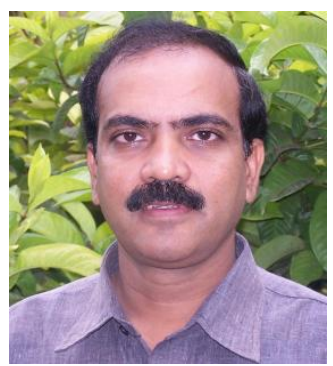

Ajay Chandak, born on 13th July 1963 did M.Tech. from IIT Bombay in 1986 and his Ph.D. in Solar Concentrators from Indore. Has 35 patents, 10 journal publications and 18 presentations at international conferences. Founder of a voluntary group PRINCE (Promoters, Researchers \& Innovators in New \& Clean Energy) www.princeindia.org At present works as freelance consultant in renewable energy. Ajay is certified energy auditor and has experience of working for United Nations and Ministry of New \& Renewable Energy, Govt. of India as consultant. 